\title{
Revision of Indian Bipaliid species with description of a new species, Bipalium bengalensis from West Bengal, India (Platyhelminthes: Tricladida: Terricola)
}

\author{
Somnath Bhakat \\ Department of Zoology, Rampurhat College, Rampurhat- 731224, West Bengal, India \\ E-mail: bhakatsomnath084@gmail.com
}

ORCID: 0000-0002-4926-2496

\begin{abstract}
A new species of Bipaliid land planarian, Bipalium bengalensis is described from Suri, West Bengal, India. The species is jet black in colour without any band or line but with a thin indistinct mid-dorsal groove. Semilunar head margin is pinkish in live condition with numerous eyes on its margin. Body length (BL) ranged from 19.00 to $45.00 \mathrm{~mm}$ and width varied from 9.59 to $13.16 \%$ BL. Position of mouth and gonopore from anterior end ranged from 51.47 to $60.00 \%$ $\mathrm{BL}$ and 67.40 to $75.00 \% \mathrm{BL}$ respectively. Comparisons were made with its Indian as well as Bengal congeners.

Salient features, distribution and biometric data of all the 29 species of Indian Bipaliid land planarians are revised thoroughly. Genus controversy in Bipaliid taxonomy is critically discussed and a proposal of only two genera Bipalium and Humbertium is suggested.
\end{abstract}

Key words: Mid-dorsal groove, black, pink head margin, eyes on head rim, dumbbell sole, 29 species, Bipalium and Humbertium 


\section{Introduction}

Terrestrial planarians are relatively species-poor group with only 822 described nomial species worldwide (Winsor 1997, Jones 1998, Sluys 1999, Carbayo et al. 2002). Over 160 species of the genus Bipalium Stimpson, 1857 are known in this Asiatic triclad group. This group was also poorly studied due to various reasons namely restricted distribution, nocturnal habit, morphological similarity with earthworm etc. In India, after independence, except a few early workers (Johri 1952, Sharma and Sharma 1977, Rout and Ghose 1979, Ramkrishna and Chauhan 1960), systematic study on this group is lacking. Recently Kawakatsu and Jayashankar (2013) reported a checklist of 27 known species with description of three unidentified Diversibipalium spp. from India. In this period of lockdown, I have surveyed my area for different species of animals from invertebrates to vertebrates. On $5^{\text {th }}$ September, 2020, I observed a land planarian on the road side in my locality. Later I studied the animal in detail and in the following days a number of specimens were collected from the same spot. The present paper is based on the description of this new species, Bipalium bengalensis n. sp.

In Bipaliid taxonomy (Family: Bipaliidae von Graff, 1896), controversy persists for a long time with new proposal of genus from time to time. Elliot (1948) introduced the genus Planaria to describe a few land planarians. Wright (1860) described some hammerhead worm from India and China under the genus Dunlopea. Later, all the species of land planarian were put in the genus Bipalium. Graff (1899) at first reported three genera of land planarian on the shape of head namely Bipalium, Perocephalus and Placocephalus. In 1998, Kawakatsu et al. erected another genus Novibipalium (new "Bipalium") for those species with reduced or absence of genital papilla. But it draws controversy as in both genera, a set of fold formed the functional penis. Ogren and Sluys (2001) proposed another genus Humbertium on the basis of entry of ovovitelloducts to the female atrium. In Humbertium, the ducts enter the female atrium anteriorly while posteriorly as in Bipalium. Later Kawakatsu et al (2002) created one more genus Diversibipalium (the "diverse Bipalium") to include all species whose anatomy of the sexual organ was unknown. In 2013, Kawakatsu and Jayashankar reported four genus viz. Bipalium, Humbertium, Novibipalium and Diversibipalium to list 27 Indian Bipaliid species with their distribution in India. The report is incomplete as there is no morphological description or biometric data of the concerned species. So in the present paper, I have revised the Indian Bipaliid species with salient features and biometric data along with their distribution to fill up the lacunae.

\section{Materials and methods}

Live planarians are collected from the moist soil surface of the road side at dawn (5.00 to 5.30 a. m.) from September 5 to September 25, 2020 in the day after rainfall. As the land planarians are nocturnal in habit, after sun rise they hide themselves under stones or soil. The collection site is full of debris, grasses, weeds and other organic matters, an ideal inhabitant of 
their prey like earthworm, small insects and other soil organisms. The specimens were collected at Suri $\left(87^{\circ} 32^{\prime} 00^{\prime \prime} \mathrm{E}, 23^{\circ} 55^{\prime} 00^{\prime} \mathrm{N}\right)$, Birbhum district, West Bengal, India (Fig. 1).

Live animal is transferred in a large watch glass containing $25-30 \% \mathrm{NaCl}$ solution. Within a few minutes, the animal died and then it is transferred to distilled water for washing. Finally the specimen is transferred to $70 \%$ alcohol for preservation. In salt solution, a very thin white mucous layer is separated from the body. In this technique, the colour and shape of the body remain intact.

Measurements of each specimen were taken within two days of preservation. All the measurements were made with a digital dial caliper to the nearest $0.1 \mathrm{~mm}$. Different measurements of body parts are presented as percentage of body length (BL) while width of sole and head rim is given as percentage of body width (BW) and head breadth (HB) respectively. Mean and standard deviation (SD) of each parameter was calculated separately. Formaldehyde (4\%) preserved old specimens (at least two years old) were also measured along with the fresh specimens.

Database.

For revision work, information was collected from literature and Tricladida

\section{Results}

\section{Description of new species}

\section{Taxonomy}

Phylum: Platyhelminthes Claus, 1887

Class: Turbellaria Ehrenberg, 1831

Order: Tricladida Lang, 1884

Family: Bipaliidae von Graff, 1896

Type species: Bipalium bengalensis sp. $\mathrm{n}$.

\section{Type material}

Holotype: 05. IX. 2020.; Suri (Vivekanandapally) $\left(87.5151^{\circ} \mathrm{E}, 23.9146^{\circ} \mathrm{N}\right)$, Birbhum district, West Bengal, India; 28.4mm BL; Zoological Museum, Department of Zoology, Rampurhat College, Rampurhat-731224, Birbhum district, West Bengal, India; Collecter: Somnath Bhakat.

Paratype: Same locality; 19.00-45.00mm BL $(n=11)$; September 5-25, 2020; all other details are same as holotype. 
Description: (Fig.1) (Table 1).

Elongated bilaterally symmetrical and dorsoventrally flattened body is with a semilunar head. The anterior portion of the body connecting the head is narrow to form neck, gradually broadens to reach maximum width at mouth region. In some specimen, mouth region is more expanded than normal, form pharyngeal swelling (Fig. 1). The posterior most part of the body is narrow with blunt tip. Head plate is semilunar in shape with numerous small eyes limited to the margin of the head, form a rim $(0.7-1 \mathrm{~mm}$ width). In live condition, when the planaria search for a suitable surface, a wavy movement is observed in the peripheral margin of the head. In normal condition, the head is slightly elevated from the surface to investigate any object but in critical condition, the worm can elevated/raised half of its body length to attach with a suitable surface (Fig. 1). Mouth opens beyond $50 \%$ and the gonopore in the $3 / 4^{\text {th }}$ of the body from anterior end. In some specimen, another yellowish circular spot is present followed by gonopore. Elevated creeping sole begins at the base of the head, extending to the tip of the posterior end where it is wider to form a dumbbell (Fig. 2).

Colour of the dorsal surface is jet black with a narrow longitudinal groove in the middle. In live condition, the head plate is pale black with pinkish rim. Auricle of semilunar head plate is pale in colour. The ventral surface is pale dark with yellowish white creeping sole in the middle (Fig. 2).

In the formaldehyde preserved old specimen (more than two years old), the body became more thick, wrinkled and tough. The dorsal surface is decolourised and turned into yellowish brown with tinge of black though anterior $1 / 4^{\text {th }}$ is black mottling. Head is blackish with yellowish margin. Ventral surface of head is whitish brown. Pale yellowish ventral is with a distinct elevated whitish sole in the middle. In one specimen, pharynx with white thick margin, is protruded through the mouth as a frill on the dorsal surface (Fig. 1).

\section{Comparative diagnosis:}

Comparisons were made on the basis of reports of the following authors for concerned species: Beauchamp, 1930; Graff, 1899; Humbert and Glaparede, 1862; Moseley, 1878; Whitehouse, 1914, 1919; Wright, 1860 (Table 3). Bipalium bengalensis differs from its congeners by several characters, the most important of which is that it lacks any longitudinal band or line on the dorsal surface while in most of the species one (B. dihangense, $H$. palnisia), two (H. dodabettae), three (B. splendens, B. andrewesi) or five (B. kewense) bands or lines are present on the dorsal surface. Moreover, present species bears a mid-dorsal thin narrow groove (indistinct in live specimen) which is absent in all other species. Among 29 Indian species, only five species viz. B. indicum, B. grayia, B. splendens, $H$. proserpina and B. smithi are reported from West Bengal. Like B. bengalensis, B. splendens and $H$. proserpina are black in colour but $B$. splendens have three black lines while in $H$. proserpina, a wide black band is present on the 
dorsal surface. The present species differs from other three Bengal species by colour pattern (black vs. other than black).

In $B$. bengalensis, location of mouth and gonopore from anterior end is longer than those of $H$. proserpina (55.22 vs. $44.01 \%$ BL and 70.55 vs. $60.00 \%$ BL respectively). Compared to $B$. smithi, head breadth and position of gonopore length is shorter in the present species (15.56 vs. $10.94 \%$ BL and 80.00 vs. $70.55 \%$ BL respectively). Distance of gonopore from anterior end is longer in B. bengalensis compared to that of B. splendens (70.55 vs. $60.00 \% \mathrm{BL}$ ) and sole is also wider to that of later species $(27.01$ vs. $22.22 \% \mathrm{BW})$. In B. indicum, though other two measurements like body width and position of gonopore from anterior end are within the range with those of $B$. bengalensis but position of mouth from anterior is shorter in the former species (50.00 vs. $55.22 \%$ BL). Moreover, the former species differs from the later by the presence of eyes in the neck.

Etymology: Latin name, genitive case, meaning "bengal" in reference to its occurrence.

\section{Distribution and habitat:}

Bipalium bengalensis is known for the type locality at Suri in West Bengal. Suri is a small town of Birbhum district, West Bengal, India. The specimens were collected from the road side of Vivekanandapally (a locality of Suri). Thick vegetation is present on both sides of the road with a few shrub like Calotropis procera, Cassia sophera etc. On both sides open drain and stagnant water provide decomposed organic matter and water to the entire vegetation throughout the year. This supports rich population of soil animals including the present Bipaliid species. Moreover, organic matters like household leftovers and faecal substance of domestic animal like cow and goat enrich the soil regularly. At this place, other soil animals like different species of earthworm, millipedes, coleopteran larva, termites, isopods, ants and their larva, spiders are common. These provide food to the population of Bipalium bengalensis. There are other solid wastes like stones, bricks, debris etc. which provide shelter to different soil animals including the present species.

\section{Revision}

Morphology and distribution of 29 Indian Bipaliid species are listed in Table 2. Morphological characters of these species in percentage of body length and body width are presented in Table 3. Besides these 29 species, Kawakatsu and Jayashankar (2013) reported three species of Diversibipalium (=Bipalium), one from Madurai and two from Bangalore. In all three species only length and width are mentioned. Although colour, shape and banding patterns were described vividly. Bipalium kewense was reported from Delhi state in the name Placocephalus kewense by Johri in 1952 and later Sharma and Sharma (1977) reported the same species from India. Patra and Aditya (2001) studied regeneration pattern of an unidentified land planarian from Darjeeling (West Bengal). The species is very long $(15-20 \mathrm{~cm})$ and wide $(1-3 \mathrm{~cm})$ with 3-5 prominent yellow or black stripe on the body. 


\section{Discussion}

In practice, while describing a species of land planarian, author always put the actual or raw data of different body parts of an individual. Then it becomes very difficult to separate different species of unequal body length on the basis of size or position of body parts. To overcome this problem, it is better to present the data related to different body parts in proportion to body length or width as because in all the symmetrical animals, size of any body part is always proportional to its body length or width. Then it will be very easy to identify different species biometrically as shown in Table 3.

Except a few (the invasive $B$. kewense), most of the species are restricted to a particular geographic area as they are less dispersed. The land planarians are stenohygric in nature (Froehlich, 1955; Winsor et al., 1998; Sluys, 1999) and feed on a wide range of invertebrates like earthworm, isopods, insect larvae, termites etc. (Du Bois Reymond Marcus, 1951; Jones et al., 1995; Ogren, 1995; Sluys, 1999). Boag et al. (1990) commented that soil moisture content, temperature and availability of food are the principal factors to determine the presence of terrestrial planarians. All the above mentioned factors are available in the present habitat for survival of a large population of $B$. bengalensis for a long time. On the basis of morphological characters, biometric data and comparison with other species, it can be concluded that $B$. bengalensis is distinctly separated from its congeners of West Bengal and should be treated as a new species of the genus Bipalium.

So far the criteria of selection of a genus in Bipaliidae indicate that there are two genera, Bipalium and Humbertium, which can be distinguished clearly by one or more points. Another genus, Diversibipalium was created from Bipalium which lack information on sexual structure though each species is separated from each other morphologically. Winsor (1983) commented that Stimpson's generic diagnosis which is based on external morphology proves to be unsatisfactory. But the argument is that gene regulates the morphology of an individual. So morphology based taxonomy should not be discarded rather it can further be verified by molecular taxonomy. The creation of a new genus (from Bipalium to Diversibipalium) on the basis of its anatomical description is not acceptable because morphologically described species after molecular taxonomy ascribed as synonymous or grouped into a species group as found in many other cases. Recently, molecular study of Mazza et al. (2016) indicates that Diversibipalium multineatum is a kin to Bipalium nobile and Novibipalium venosum appears to be a member of Bipalium species group. So it can be concluded that all the following genera are synonymous of Bipalium:

Sphyrocephalus Bleeker, 1844; Planaria Elliot,1848; Dunlopea Wright, 1860; Sphaerocephalus Loman, 1888; Perocephalus Graff, 1896; Placocephalus Graff, 1896; Novibipalium Kawakatsu et al., 1998 and Diversibipalium Kawakatsu, 2002. 
Table 1. Biometric data of Bipalium bengalensis $\mathrm{n}$. sp. (BL in mm.).

\begin{tabular}{|c|c|c|c|c|c|c|}
\hline \multirow{2}{*}{$\begin{array}{l}\text { S1. } \\
\text { No. }\end{array}$} & \multirow[t]{2}{*}{ Parameter } & \multirow[t]{2}{*}{ Holotype } & \multicolumn{2}{|c|}{ Paratype $(\mathrm{n}=11)$} & \multicolumn{2}{|c|}{ Old specimens $(\mathrm{n}=3)$} \\
\hline & & & Range & Mean \pm SD & Range & Mean \\
\hline 1. & Body length (BL) & 28.4 & $19.00-45.00$ & & $37.8-48.00$ & 41.27 \\
\hline \multicolumn{7}{|c|}{$\% \mathrm{BL}$} \\
\hline 2. & $\begin{array}{l}\text { Max. body width } \\
\text { (BW) }\end{array}$ & 10.56 & $9.59-13.16$ & $10.71 \pm 1.13$ & $10.42-12.63$ & 11.56 \\
\hline 3. & Head breadth (HB) & 10.92 & $10.00-13.68$ & $10.94 \pm 1.08$ & $10.00-12.63$ & 11.69 \\
\hline 4. & Neck breadth & 6.34 & $5.75-7.89$ & $6.35 \pm 0.71$ & $6.67-8.16$ & 7.59 \\
\hline 5. & $\begin{array}{l}\text { Mouth from } \\
\text { anterior end }\end{array}$ & 60.56 & $51.47-60.00$ & $55.22 \pm 2.68$ & $46.25-57.89$ & 51.64 \\
\hline 6. & $\begin{array}{l}\text { Gonopore from } \\
\text { anterior end }\end{array}$ & 76.76 & $67.40-75.00$ & $70.55 \pm 2.84$ & $61.90-74.21$ & 66.90 \\
\hline 7. & $\begin{array}{l}\text { Distance between } \\
\text { mouth and } \\
\text { gonopore }\end{array}$ & 16.20 & $13.33-18.42$ & $15.57 \pm 1.34$ & $11.11-18.33$ & 15.25 \\
\hline 8. & Thickness & 5.01 & $4.56-6.48$ & $5.55 \pm 0.65$ & $7.08-8.25$ & 7.67 \\
\hline \multicolumn{7}{|c|}{$\% \mathrm{BW}$} \\
\hline 9. & Sole width & 29.24 & $25.84-28.75$ & $27.01 \pm 1.03$ & $28.57-30.25$ & 29.53 \\
\hline \multicolumn{7}{|c|}{$\% \mathrm{HB}$} \\
\hline 10. & Head rim & 16.24 & $14.28-16.34$ & $15.54 \pm 0.65$ & $12.25-13.25$ & 12.76 \\
\hline
\end{tabular}

Table 2. List of Indian Bipaliid species with their salient features and distribution in India.

\begin{tabular}{|l|l|l|l|l|}
\hline $\begin{array}{l}\text { Sl. } \\
\text { No. }\end{array}$ & Species & Salient features & Distribution & Reference \\
\hline 1. & $\begin{array}{l}\text { Bipalium } \\
\text { andrewesi }\end{array}$ & $\begin{array}{l}\text { Dark reddish brown, 3 longitudinal } \\
\text { black stripes, neck with narrow black } \\
\text { transverse band }\end{array}$ & Nilgiri hills & $\begin{array}{l}\text { Whitehouse, } \\
1919\end{array}$ \\
\hline 2. & B. brunneum & $\begin{array}{l}\text { Rusty brown with 3 longitudinal dark } \\
\text { stripe, sole purplish grey, ventral dull, } \\
\text { grayish outer edge }\end{array}$ & $\begin{array}{l}\text { Cochin-S. } \\
\text { India, } \\
\text { Kumaon }\end{array}$ & $\begin{array}{l}\text { Whitehouse, } \\
1919\end{array}$ \\
\hline 3. & B. delicatum & $\begin{array}{l}\text { Light and dark brown, 2 apparently } \\
\text { bleached patches on the ventral } \\
\text { surface, eyes continued upto half the } \\
\text { length of the body }\end{array}$ & $\begin{array}{l}\text { Rotung, } \\
\text { Assam }\end{array}$ & $\begin{array}{l}\text { Whitehouse, } \\
1914\end{array}$ \\
\hline 4. & B. dihangense & $\begin{array}{l}\text { Dull reddish brown, reddish tint at the } \\
\text { sides, a mid-dorsal line, brownish } \\
\text { pink ventral, eyes on head and neck. }\end{array}$ & $\begin{array}{l}\text { Valley of } \\
\text { Dihang river, } \\
\text { Assam }\end{array}$ & $\begin{array}{l}\text { Whitehouse, } \\
1914\end{array}$ \\
\hline 5. & $\begin{array}{l}\text { B. } \\
\text { ferudpoorrense }\end{array}$ & $\begin{array}{l}\text { Greenish brown with a line of } \\
\text { yellowish brown. }\end{array}$ & $\begin{array}{l}\text { Bangar and } \\
\text { Naga hills }\end{array}$ & Wright, 1860 \\
\hline 6. & B. flowei & $\begin{array}{l}\text { Dorsal dark brown, 2 black bands } \\
\text { with a orange stripe. }\end{array}$ & Nilgiri & $\begin{array}{l}\text { von Graff, } \\
1899\end{array}$ \\
\hline 7. & B. giganteum & Dull brown, ventral blue grey, head & Assam & Whitehouse, \\
\hline
\end{tabular}




\begin{tabular}{|c|c|c|c|c|}
\hline & & paler, sole form arrow head. & & 1914 \\
\hline 8. & B. grayia & $\begin{array}{l}\text { Triangular head lobe, brownish } \\
\text { colour marked with yellow, } 3 \\
\text { longitudinal narrow line.. }\end{array}$ & $\begin{array}{l}\text { Naga hills, } \\
\text { Bengal }\end{array}$ & Wright, 1860 \\
\hline 9. & $\begin{array}{l}\text { B. indicum } \\
(=\text { indica })\end{array}$ & $\begin{array}{l}\text { Darkish dull brown and pale biscuit } \\
\text { colour, neck with darker pigment, } \\
\text { eyes on head and neck, broad median } \\
\text { longitudinal band, sole white. }\end{array}$ & $\begin{array}{l}\text { Calcutta, } \\
\text { Coimbatore }\end{array}$ & $\begin{array}{l}\text { Whitehouse, } \\
1919\end{array}$ \\
\hline 10. & $\begin{array}{l}\text { B. } \\
\text { kirckpatricki }\end{array}$ & Brown with a mid dorsal band. & India & $\begin{array}{l}\text { von Graff, } \\
1899\end{array}$ \\
\hline 11. & $\begin{array}{l}\text { B. lunata }(B= \\
\text { Planaria })\end{array}$ & $\begin{array}{l}\text { Dark brownish black, head pale with } \\
\text { whitish border and edge pale brown. }\end{array}$ & $\begin{array}{l}\text { Assam, } \\
\text { Madras, } \\
\text { Malabar }\end{array}$ & Elliot, 1848 \\
\hline 12. & B. roonwali & $\begin{array}{l}\text { Dorsal dark grey with thick median } \\
\text { blue black stripe, deep median line } \\
\text { prominent at mouth, ventral creamy } \\
\text { white. }\end{array}$ & Nilgiri & $\begin{array}{l}\text { Ramkrishna } \\
\text { \& Chauhan, } \\
1960\end{array}$ \\
\hline 13. & B. rotungense & $\begin{array}{l}\text { Bluish grey with touches of brown, } 3 \\
\text { longitudinal dark lines, eyes confined } \\
\text { to head rim. }\end{array}$ & $\begin{array}{l}\text { Rotung, } \\
\text { Assam }\end{array}$ & $\begin{array}{l}\text { Whitehouse, } \\
1914\end{array}$ \\
\hline 14. & B. smithi & $\begin{array}{l}\text { Bluish black, sole side with bluish } \\
\text { green tinge. }\end{array}$ & $\begin{array}{l}\text { Darjeeling } \\
\text { (W. B.) }\end{array}$ & $\begin{array}{l}\text { von Graff, } \\
1899\end{array}$ \\
\hline 15. & B. sordidum & $\begin{array}{l}\text { Deep brown with profuse black } \\
\text { mottling, median narrow band, } \\
\text { reddish brown side. }\end{array}$ & $\begin{array}{l}\text { Yem bung } \\
\text { river, Assam }\end{array}$ & $\begin{array}{l}\text { Whitehouse, } \\
1914\end{array}$ \\
\hline 16. & B. splendens & $\begin{array}{l}3 \text { longitudinal jet black lines, yellow } \\
\text { sole with side diffused black line, } \\
\text { eyes few. }\end{array}$ & $\begin{array}{l}\text { Kurseong (W. } \\
\text { B.), } \\
\text { Cherrapungi }\end{array}$ & $\begin{array}{l}\text { Whitehouse, } \\
1919\end{array}$ \\
\hline 17. & B. sylvestre & $\begin{array}{l}\text { Dark brown, } 3 \text { longitudinal black } \\
\text { lines. }\end{array}$ & Cochin state & $\begin{array}{l}\text { Whitehouse, } \\
1919\end{array}$ \\
\hline 18. & B. whitehousei & $\begin{array}{l}3 \text { longitudinal stripe, head with } 2 \\
\text { semicircular bands, outer black inner } \\
\text { pale buff, sole white. }\end{array}$ & $\begin{array}{l}\text { Rotung, } \\
\text { Assam }\end{array}$ & $\begin{array}{l}\text { Ogren \& } \\
\text { Kawakatsu, } \\
1987\end{array}$ \\
\hline 19. & B. bengalensis & $\begin{array}{l}\text { Dorsal deep black, no band but a } \\
\text { narrow groove in the middle, ventral } \\
\text { pale, sole whitish, eyes on head rim }\end{array}$ & Suri (W. B.) & Present study \\
\hline 20. & $\begin{array}{l}\text { Humbertium } \\
\text { core }\end{array}$ & $\begin{array}{l}\text { Dorsal brown, a longitudinal band in } \\
\text { the middle of the body. }\end{array}$ & $\begin{array}{l}\text { Palnis, } \\
\text { Pumbarai }\end{array}$ & $\begin{array}{l}\text { Beauchamp, } \\
1930\end{array}$ \\
\hline 21. & B. depressum & $\begin{array}{l}\text { Longitudinal band in the middle, eyes } \\
\text { on head and neck. }\end{array}$ & $\begin{array}{l}\text { Attakatti, } \\
\text { Shola, Ibex } \\
\text { hill }\end{array}$ & $\begin{array}{l}\text { Beauchamp, } \\
1930\end{array}$ \\
\hline 22. & H. dodabettae & $\begin{array}{l}2 \text { longitudinal band, eyes on head and } \\
\text { neck. }\end{array}$ & Nilgiri & $\begin{array}{l}\text { Beauchamp, } \\
1930\end{array}$ \\
\hline 23. & B.kewense & $\begin{array}{l}\text { Light ochre with } 5 \text { black to grey long } \\
\text { stripe, median black and narrow, head } \\
\text { plate grayish with light ochre margin }\end{array}$ & $\begin{array}{l}\text { Cosmopoliton } \\
\text { Jammu \& } \\
\text { kashmir }\end{array}$ & $\begin{array}{l}\text { Moseley, } \\
1878\end{array}$ \\
\hline
\end{tabular}




\begin{tabular}{|l|l|l|l|l|}
\hline 24. & H. palnisia & $\begin{array}{l}\text { Brown, semicircular head, a broad } \\
\text { longitudinal band, sole brown. }\end{array}$ & $\begin{array}{l}\text { Palnis, S. } \\
\text { India }\end{array}$ & $\begin{array}{l}\text { Beauchamp, } \\
1930\end{array}$ \\
\hline 25. & B. rigaudi & $\begin{array}{l}\text { Somber colour, parallel longitudinal } \\
\text { band, median black line. }\end{array}$ & Assam & $\begin{array}{l}\text { Von Graff, } \\
1894\end{array}$ \\
\hline 26. & B. univittatum & $\begin{array}{l}\text { Semicircular whitish head, dorsal } \\
\text { violet brown, longitudinal white band } \\
\text { on the lateral side, head with eye. }\end{array}$ & Madras & Grube, 1866 \\
\hline 27. & B. vinosum & $\begin{array}{l}\text { Non-sexual, uniform vinous red, } \\
\text { pharyngeal region pale buff, eye one } \\
\text { or two rows on head margin. }\end{array}$ & Andaman & $\begin{array}{l}\text { Kaburaki, } \\
1925\end{array}$ \\
\hline 28. & Bipalium sp. & $\begin{array}{l}\text { 3-5 prominent yellow or black stripe, } \\
\text { small eyes on head margin. }\end{array}$ & Darjeeling & $\begin{array}{l}\text { Beauchamp, } \\
1930\end{array}$ \\
\hline 29. & H. proserpina & $\begin{array}{l}\text { Wide black band on dorsal } \\
\text { interspersed by a white thin line, 4 } \\
\text { lateral band running parallel to } \\
\text { median black band, dorsal jet black. }\end{array}$ & $\begin{array}{l}\text { Hooker state, } \\
\text { Nadu-vattum, } \\
\text { Nilgiri }\end{array}$ & $\begin{array}{l}\text { Humbert and } \\
\text { Glaparede, } \\
1862)\end{array}$ \\
\hline
\end{tabular}

Table 3. Biometric data of Indian Bipaliid species.

\begin{tabular}{|c|c|c|c|c|c|c|c|c|}
\hline \multirow{3}{*}{$\begin{array}{l}\text { Sl. } \\
\text { No. }\end{array}$} & \multirow[t]{3}{*}{ Species } & \multicolumn{7}{|c|}{ Character } \\
\hline & & \multirow{2}{*}{$\begin{array}{l}\mathrm{BL} \\
(\mathrm{mm})\end{array}$} & \multicolumn{5}{|c|}{$\% \mathrm{BL}$} & \multirow{2}{*}{$\begin{array}{l}\% \text { BW } \\
\text { Sole }\end{array}$} \\
\hline & & & $\begin{array}{l}\text { Body } \\
\text { width }\end{array}$ & $\begin{array}{l}\text { Head } \\
\text { breadth }\end{array}$ & $\begin{array}{l}\text { Mouth } \\
\text { from } \\
\text { anterior } \\
\text { end }\end{array}$ & $\begin{array}{l}\text { Gonopore } \\
\text { from } \\
\text { anterior } \\
\text { end }\end{array}$ & Thickness & \\
\hline 1. & B. andrewesi & 10 & 30.00 & 40.00 & 60.00 & - & - & 33.33 \\
\hline 2. & B. brunneum & 58 & 15.52 & 10.34 & 41.38 & 56.90 & & 33.33 \\
\hline 3. & B. delicatum & $\begin{array}{l}39- \\
55\end{array}$ & $\begin{array}{l}9.09- \\
10.26\end{array}$ & - & $\begin{array}{l}38.46- \\
54.55\end{array}$ & $\begin{array}{l}89.09- \\
89.74\end{array}$ & - & - \\
\hline 4. & B. dihangense & 92 & 7.61 & - & 50.00 & 60.87 & - & - \\
\hline 5. & $\begin{array}{l}B . \\
\text { ferudpoorrense }\end{array}$ & 10.16 & - & - & 50.00 & - & - & - \\
\hline 6. & B. floweri & 33.25 & 14.46 & 13.53 & 64.06 & - & - & - \\
\hline 7. & B. giganteum & 217 & 6.19 & - & $\geq 50.00$ & $\geq 68.00$ & & \\
\hline 8. & B. grayi & & & & & & & \\
\hline 9. & $\begin{array}{l}\text { B. indicum } \\
(=\text { indica })\end{array}$ & $\begin{array}{l}30- \\
40\end{array}$ & $\begin{array}{l}10.00- \\
12.50 \\
\end{array}$ & - & 50.00 & 75.00 & & \\
\hline 10. & B. kirckpatricki & 72 & 11.81 & - & 48.61 & 56.94 & - & - \\
\hline 11. & $\begin{array}{l}\text { B. lunata }(B= \\
\text { Planaria }\end{array}$ & 12.70 & - & - & $>50$ & - & & \\
\hline 12. & B. roonwali & 36.2 & 16.85 & 17.13 & 52.76 & 72.93 & - & - \\
\hline 13. & B. rotungense & 55 & 12.73 & - & 58.18 & 76.36 & - & - \\
\hline
\end{tabular}




\begin{tabular}{|l|l|l|l|l|l|l|c|c|}
\hline 14. & B. smithi & 45 & 13.33 & 15.56 & 53.33 & 80.00 & - & 33.33 \\
\hline 15. & B. sordidum & 28 & 16.07 & 10.71 & 50.00 & 75.00 & & \\
\hline 16. & B. splendens & 90 & 5.00 & 3.33 & 50.00 & 60.00 & & 22.22 \\
\hline 17. & B. sylvestre & 50 & 10.00 & 12.00 & 56.00 & - & - & 40.00 \\
\hline 18. & B. whitehousei & 52 & 3.85 & - & $\geq 50.00$ & $\geq 60.00$ & & \\
\hline 19. & B. bengalensis & $19-$ & $10.71 \pm$ & $10.94 \pm$ & $55.22 \pm$ & $70.55 \pm$ & $5.55 \pm$ & $27.01 \pm$ \\
& & 45 & 1.13 & 1.08 & 2.68 & 2.84 & 0.65 & 1.03 \\
\hline 20. & H. core & 23 & 17.39 & - & 52.17 & 71.74 & - & $25-33$ \\
\hline 21. & B. depressum & $15-$ & $17.39-$ & - & $46.67-$ & $63.33-$ & $8.70-$ & - \\
& & 23 & 26.67 & & 52.17 & 76.09 & 20.00 & \\
\hline 22. & H. dodabettae & 18 & 19.44 & - & 50.00 & 66.67 & 11.11 & 33.33 \\
\hline 23. & B. kewense & 78 & 6.15 & 4.49 & 39.74 & 47.44 & - & 22.92 \\
\hline 24. & H. palnisium & 21 & 16.67 & - & 50.00 & 59.52 & - & 25.00 \\
\hline 25. & B. rigaudi & 38 & 12.15 & - & 47.37 & 59.21 & - & - \\
\hline 26. & B. univittatum & 28 & 23.21 & - & 60.71 & 78.57 & - & - \\
\hline 27. & B. vinosum & 52 & 7.69 & - & 50.00 & - & - & 25.00 \\
\hline 28. & Bipalium sp. & 16 & 15.63 & - & 50.00 & 68.75 & 11.25 & - \\
\hline 29. & H. proserpina & 43.40 & 11.29 & 11.75 & 44.01 & 59.91 & - & - \\
\hline
\end{tabular}

\section{Acknowledgement}

I am deeply indebted to my son Dr. Soumendranath Bhakat of Lund University, to take interest on the species and my wife for her continuous inspiration in this critical period of lockdown. I am also grateful to my colleagues of Rampurhat College for their cooperation and Mr. Sourav Saha of Satyajit Roy Film and Television Institute, Kolkata for technical help. 


\section{References}

Boag, B.; Yeates, G. W. and Jones, P. M. (1990). Limitations to the distribution and spread of terrestrial flatworms with special reference to the New Zealand flat worm (Artioposthia triangulata). Pedobiologia 42: 495-503.

Carbayo, F.; Leal-Zanclet, A. M. and Vieira, E. M. (2002). Terrestrial flatworm (Platyhelminthes: Tricladida: Terricola) diversity versus man-induced disturbance in an ombrophilons forest in southern Brazil. Biodiversity and Conservation 11: 1091-1104.

De Beauchamp, P. (1930). Turbellaries Triclades de l'Inde meridionale. Rev. Suisse Zool. 37(23): 673-746.

Du Bois Reymond Marcus, E. (1951). On South American Geoplanids. Boletim da Faculdade de Filosofia, Ciencias e Letras da Universidade de sao Paulo. 16: 217-255.

Elliot, W. (1848). Description of a new species of terrestrial planaria. Madras J. Lit. Sci. 15: 162 167.

Froehlich, E. M. (1955). Sobre species brasileiras do genero Geoplana. Boletim da Faculdade de Filosofia, Ciencias e Letras da Univerisidade de sao Paulo. 19: 289-369.

Grube, E. (1866). Beschreibungen neuer von der Novara-Expedition Verhandl. D. k. k. Zool.bot. Ges. Wien, 16: 173-184.

Humbert, I. A. and Glaparede, M. E. (1862). Description de quelques espeeces nouvelles de planaires terrestres de Ceylon. Mem. Soc. Phys. Geneeve. 16: 293-311.

Johri, L. N. (1952). A report on Turbellarian Placocephalus kewense from Delhi State and its feeding behaviour on the live earthworm, Pheretima posthuma. Sci. \& Cult. 18: 291.

Jones, H. D. (1998). The African and European land planarian faunas, with an identification guide for field workers in Europe. Pedobiologia 42: 477-489.

Jones, H. D., Cumming, M. S. and Kennaugh, J. H. (1995). The anatomy of microplasma termitophaga from Zimbawe and Kenya: a confirmation of the subfamily and genus. Hydrobiologia 305: 121-126.

Kaburaki, T. (1925). Planarians from the Andamans. Rec. Ind. Mus. 27: 29-32.

Kawakatsu, M. and Jayashankar, M. (2013). A list of known Bipaliid land planarian species from India, with a record of three Diversibipalium spp. Kawakatsu's Web Library on Planarians: December 30. 
Kawakatsu, M.; Ogren, H. E. and Froehlich, E. M. (1998). The taxonomic revision of several homonyms in the genus Bipalium, family Bipaliidae (turbellaria, Seriata, Tricladida, Terricola). Bull. Fuji Women's College 36(II):83-93.

Kawakatsu, M.; Ogren, R. E.; Froehlich, E. M. and Sasaki, G. Y. (2002). Miscellaneous papers on Turbellarians, Article II. Additions and corrections of the previous land planarian indices of the world (Turbellaria, Seriata, Tricladida, Terricola) - 10. Bull. Fuji Women's Univ. 40(II): $162-177$.

Mazza, G.; Menchetti, M.; Sluys, R.; Sola, E.; Rintort, M.; Tricarico, E.; Justine, J. L.; Cavigioli, L. and Mori, E. (2016). First report of the land planarian Diversibipalium multilineatum (Makino \& Shirasawa, 1983) (Platyhelinthes, Tricladida, Continenticola) in Europe. Zootaxa 4067(5): 577-580.

Moseley, H. N. (1878). Description of a new species of land planarian from the hothouses at Kew Gardens. Ann. Mag. Nat. Hist. 5(1):237-239.

Ogren, R. E. (1995). Predation behaviour of land planarians. Hydrobiologia. 305: 105-111.

Ogren, R. E. and Kawakatsu, M. (1987). Index to the speciesof the genus Bipalium (Turbellaria, Tricladida, Terricola). Bull. Fuji Women's College. 25 (II): 79-119.

Ogren, R. E. and Sluys, R. (2001). The genus Humbertium gen. nov., a new taxa of the land planarian family Bipaliidae (Tricladida, Terricola). Belg. J. Zool. 131 (Supplement 1):201-204.

Patra, B. C. and Aditya, A. K. (2001). Circular form of regeneration in an unidentified species of land planarians, Bipalium sp. Indian J. Expt. Biol. 39:496-499.

Ramkrishna, G. and Chauhan, B. S. (1960). Description of Bipalium roonwali sp. nov., with notes on two other species of the family Bipaliidae from the Nilgiris, India. Rec. Indian Mus. 58: 53-56.

Rout, S. K. and Ghose, K. C. (1979). The Planaria, Bipalium indica an effective predator of Achatina fulica. Bull. Zool. surv. India 2(1): 101-102.

Sharma, B. D. and Sharma, T. J. (1977). Occurrence of Bipalium kewense Moseley (Turbellaria: Tricladida) in India. J. Bombay Nat. Hist. Soc. 74: 205.

Sluys, R. (1999). Global diversity of land planarians (Platyhelminthes, Tricladida, Terricola): a new indicator taxon in biodiversity and conservation studies. Biodiversity and Conservation 8: 1663- 1681.

Stimpson, W. (1857). Prodromus descriptions animalium evertebratorum quae in Expeditione ad Oceanum, Pacificum Septentrionalem a Republica Federata missa, Johanne Rodgers Duce, observavit et descripsit. Proc. Acad. Nat. Sci. Philadelphia, 9: 19-31. 
von Graff, L. (1894). Description d'une planaire terrestre du Tonkin. Bull. Soc. Zool. France, 19: 100-101.

von Graff, L. (1896). Uber das System und die geographische Verbreitung der Land planarian. Verhandl. Deutsch. Zool. Gesellschaft 6: 61-75.

von Graff, L. (1899). Monographie der Turbellarien. II. Tricladida Terricola (Landplanarien). Pp. i-ixv + 1-574; Atlas von Achtundfunfzig Tafeln zur Monographie der Turbellarien. II. Tricladida Terricolen (Landplanarien). Pls. I-LVIII. Verlag von Wilhelm Engelmann. Leipzig.

Whitehouse, R. H. (1914). XXXVI, Land Planarians. Recor. Indian Mus. 8(6): 455-464.

Whitehouse, R. H. (1919). Indian land planarians. Recor. Indian Mus. 16: 29-40.

Winsor, L. (1983). A revision of the cosmopolitan land planarian Bipalium kewense Moseley, 1878 (Turbellaria: Tricladida: Terricola). Zool. J. Linn. Soc. 79: 61-100.

Winsor, L. (1997). The biodiversity of terrestrial flatworms (Tricladida: Terricola) in Queensland: A preliminary report. Memoirs of Museum Victoria. 56: 575-579.

Winsor, L.; Johms, P. M. and Yeates, G. W. (1998). Introduction, and ecological and systematic background to the terricola (Tricladida). Pedobiologia 42: 389-404.

Wright, E. P. (1860). Notes on Dunlopea. Ann. Mag. Nat. Hist. 6(3): 54-56. 

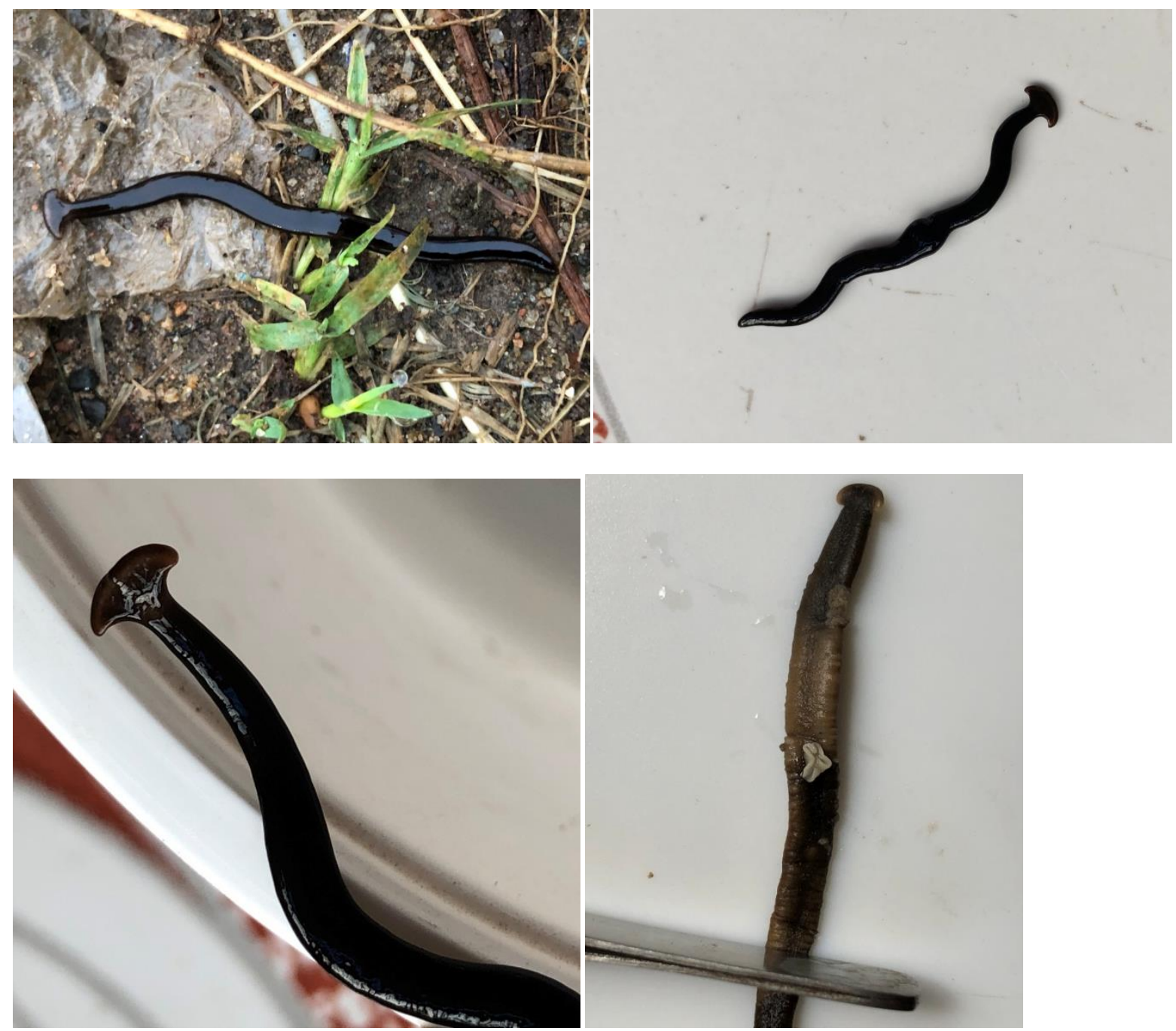

Fig. 1. Bipalium bengalensis $\mathrm{sp}$. $\mathrm{n}$.in nature, the planarian showing pharyngeal swelling (in the middle of the body), elevated anterior half of the body, protruded pharynx from the dorsal surface (white frill). (clockwise from upper left).

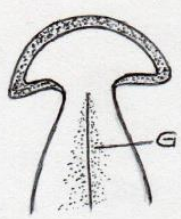

A

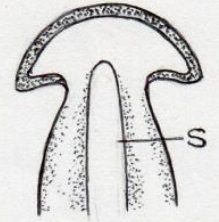

$B$
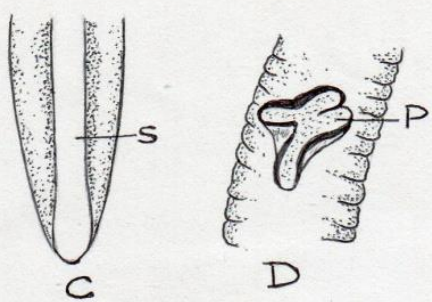

Fig. 2. Bipalium begalensis sp. n. A. Anterior portion showing head and median groove (G), B. Ventral portion showing sole (S), C. Posterior end showing dumbbell sole (S), D. Enlarged protruded pharynx $(\mathrm{P})$ with wrinkled body margin (in preserved specimen). 
bioRxiv preprint doi: https://doi.org/10.1101/2020.11.08.373076; this version posted November 9, 2020. The copyright holder for this preprint (which was not certified by peer review) is the author/funder, who has granted bioRxiv a license to display the preprint in perpetuity. It is made available under aCC-BY-NC-ND 4.0 International license. 